\title{
PII S0016-7037(98)00135-5
}

\section{$\mathrm{CO}_{2}$-depleted fluids from mid-ocean ridge-flank hydrothermal springs}

\author{
Francis J. Sansone, ${ }^{1}$ Michael J. Mottl, ${ }^{1}$ Eric J. Olson, ${ }^{2}$ C. Geoffrey Wheat, ${ }^{3}$ and Marvin D. Lilley ${ }^{2}$ \\ 'Department of Oceanography, University of Hawaii, Honolulu, Hawaii 96822, USA \\ ${ }^{2}$ School of Oceanography, University of Washington, Seattle, Washington 98195, USA \\ ${ }^{3}$ West Coast NURP Center, Moss Landing, California 95039, USA
}

(Received October 15, 1997; accepted in revised form March 19, 1998)

\begin{abstract}
Hydrothermal spring fluids were collected from Baby Bare, a basement outcrop on the sedimentcovered eastern flank of the Juan de Fuca Ridge overlying 3.5 Ma-old crust. These waters are venting at $25^{\circ} \mathrm{C}$ but have cooled from $64^{\circ} \mathrm{C}$ within the upper $200-300 \mathrm{~m}$ of the upflow zone during their ascent. Unlike ridge-axis hydrothermal vent fluids previously sampled, the total $\mathrm{CO}_{2}$ content of the endmember spring fluids $\left(0.85 \mu \mathrm{mol} \mathrm{kg}^{-1}\right)$ is depleted with respect to bottom seawater. The very low alkalinities $\left(0.43 \mathrm{meq} \mathrm{L}^{-1}\right)$ and high $\mathrm{Ca}^{2+}$ concentrations $\left(55 \mathrm{mmol} \mathrm{kg}{ }^{-1}\right)$ of endmember spring fluids suggest that the removal of $\mathrm{C}$ in the spring fluids is associated with carbonate precipitation in the igneous basement. Assuming that $8-20 \%$ of the total ridge-flank heat loss rate of $50 \times 10^{18} \mathrm{cal} \mathrm{yr}^{-1}(6.6 \mathrm{TW})$ is removed by porewater advecting from the sediment at $\geq 25^{\circ} \mathrm{C}$ (an upper limit dictated by the global input rate of $\mathrm{Mg}^{+2}$ to the oceans; Mottl and Wheat, 1994), a maximum global carbon sink of $1.0-2.6 \times 10^{11} \mathrm{~mol} \mathrm{yr}^{-1}\left(1.2-3.1 \mathrm{Mton}^{-\mathrm{C} \mathrm{yr}^{-1}}\right)$ and a maximum global alkalinity sink of $140-340 \times 10^{9} \mathrm{eq} \mathrm{yr}^{-1}$ are calculated for warm $\left(\geq 25^{\circ} \mathrm{C}\right)$ ridge-flank hydrothermal circulation. This carbon flux is only $2-5 \%$ of current estimates of subaerial and submarine volcanic $\mathrm{CO}_{2}$ emissions $\left(\sim 50 \times 10^{11} \mathrm{~mol} \mathrm{yr}^{-1}\right)$, indicating that hydrothermal alteration of oceanic crust on young mid-ocean ridge flanks at temperatures of a few tens of degrees Celsius is only a relatively minor sink for carbon on a global basis. It is still possible, however, that ridge-flank alteration at lower temperatures $\left(<25^{\circ} \mathrm{C}\right)$ is an important component of the global carbon budget. Copyright $(1) 1998$ Elsevier Science Ltd
\end{abstract}

\section{INTRODUCTION}

\subsection{Ridge-Flank Hydrothermal Circulation}

Hydrothermal circulation of seawater through the oceanic crust plays an important role in many geologic and oceanographic processes, including heat loss from the earth, aging of the oceanic crust, and geochemical cycles of the elements. While the most spectacular result of this process is found along the mid-ocean ridge axis in the form of high-temperature $\left(\sim 350^{\circ} \mathrm{C}\right)$ springs that deposit sulfide minerals, most of the flux of both heat and seawater in fact occurs through the mid-ocean ridge flanks. It has long been known that conductive heat flow measured on young oceanic crust is much lower than the total heat flow predicted by various models for a cooling lithospheric plate. This discrepancy is attributed to advective heat loss from the crust, mainly in the form of heated seawater that exits the crust as warm or hot springs along the ridge flanks.

Estimates of the amount of heat loss from advection of seawater through the crust range from 53 to $76 \times 10^{18} \mathrm{cal} \mathrm{yr}^{-1}$ (7.0-10.1 TW), with a best estimate of $65 \times 10^{18} \mathrm{cal} \mathrm{yr}^{-1}(8.7$ TW) (Wolery and Sleep, 1976; Anderson et al., 1977; Sleep and Wolery, 1978; Langseth and Anderson, 1979; Sclater et al., 1980). This represents about $20 \%$ of the total heat loss rate from the earth, or about $30 \%$ of the rate from the seafloor; this is also more than three times the rate along the mid-ocean ridge axis. Because this heat is lost at lower temperatures, the seawater flux through the flanks is more than ten times that at the axis. Seawater advection cools the crust out to a mean age of 65 Ma (Sclater et al., 1980), over more than a third of the ocean floor (Anderson et al., 1979). This process is also important due to its alteration of the oceanic crust, and the accompanying changes in the crust's ehemistry, mineralogy, and physical properties (e.g., Staudigel and Hart, 1983; Mottl and Wheat, 1994; Alt, 1995).

\subsection{Ridge-Flank Crustal Alteration and Associated Porewater Modification}

The modification of porewater major-ion composition in ridge-flank settings has been shown to be dominated by (1) loss of $\mathrm{Mg}^{2+}$ and addition of $\mathrm{Ca}^{2+}$ resulting from basalt-seawater reactions, and (2) subsequent loss of alkalinity and $\mathrm{Ca}^{2+}$ from precipitation of $\mathrm{CaCO}_{3}$ (e.g., Sayles and Manheim, 1975; Lawrence et al., 1975; Gieskes, 1983; Mottl et al., 1983; Mottl, 1989). Moreover, data from the Deep Sea Drilling Project (DSDP) and the Ocean Drilling Program (ODP) have provided evidence of potentially large scale low-temperature hydrothermal alteration of oceanic crust on ridge flanks (e.g., Alt and Honnorez, 1984; Alt et al., 1986, 1992; Staudigel et al., 1989; Alt, 1995; Alt et al., 1996; Teagle et al., 1996). However, there is disagreement as to the magnitude of these reactions on a global scale, a controversy that is complicated by the lack of suitable samples of ridge-flank crust from deep drilling cores or other sources. Specifically, there has been a vigorous debate as to whether late-stage hydrothermal alteration of oceanic crust is a major global sink of carbon on geological time scales (e.g., Staudigèl et al., 1989; Berner, 1990; Staudigel, 1990; François and Walker, 1992; Kadko et al., 1995; Brady and Gíslason, 1997).

. In the absence of samples of oceanic crust from a range of locations to help resolve these issues, an examination of the venting fluids from ridge-flank hydrothermal sites may provide valuable complementary information on the dominant reactions associated with late-stage hydrothermal processes and the degree to which these reactions are globally uniform. This paper 


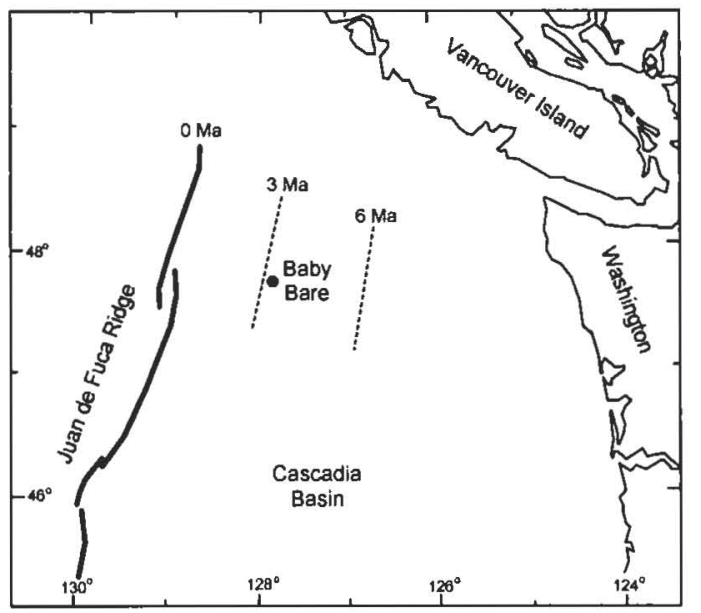

Fig. 1. Location of the study site on the eastern flank of the Juan de Fuca Ridge overlying 3.5 Ma-old crust. Bold north-south lines mark the location of the ridge axis. Dashed lines indicate isochrons for the oceanic crust. Adapted from Davis et al. (1989).

provides initial data on the inorganic carbon chemistry of spring fluids collected from such a study.

\section{STUDY SITE}

The eastern flank of the Juan de Fuca Ridge has become one of the most thoroughly studied ridge flanks over the past decade. The FlankFlux 90 and 92 cruises studied the hydrology of three outcrops, located on a pair of adjacent 3.5-3.8 Ma-old, north-south, ridge-axis-parallel basement ridges that are almost entirely buried by turbidite sediments typically a few hundred meters thick (Wheat and Mottl, 1994). Except for the young crustal age, these outcrops are typical of a large number of similar outcrops that protrude through otherwise continuous sediment cover on ridge flanks throughout the oceans. It has long been suggested that such outcrops play a key role in seafloor hydrology, acting as direct conduits between igneous basement and the oceans, concentrating vertical flow and inducing lateral flow of seawater over large distances through basement (Mottl and Wheat, 1994, and references therein). These cruises demonstrated that the outcrops are sites of hydrothermal upwelling of highly altered, $\mathrm{Mg}$-depleted seawater that is precipitating hydrothermal clays and ferromanganese deposits (Mottl et al., 1998).

The smallest outcrop, Baby Bare, is $0.5 \mathrm{~km}^{2}$ and rises $70 \mathrm{~m}$ above the sediment and $300 \mathrm{~m}$ above the buried ridge crest (Fig. 1). Extensive heat flow and seismic reflection surveys indicate that the buried basement interface in the region is isothermal at $60-70^{\circ} \mathrm{C}$ (Davis et al., 1992).

In August 1995 a team led by M. J. Mottl and C. G. Wheat successfully dove on the outcrops with the manned submersible Alvin in order to conduct fine-scale measurements and collect samples for a definitive test of their model of ridge flank hydrology. Heat flows exceeding $70 \mathrm{~W} \mathrm{~m}^{-2}$, indicating upward porewater advection at velocities $>300 \mathrm{~cm} \mathrm{yr}^{-1}$, were measured throughout a large region near the summit of Baby Bare (Wheat et al., 1995; Mottl et al., 1998). In addition, venting of highly altered, seawater-derived fluids at a temperature of $25^{\circ} \mathrm{C}$ was observed at hydrothermal springs approximately centered in the region with the highest heat flow (Mottl et al., 1995, 1998). No other vents this hot or this active have ever been found on a mid-ocean ridge flank, particularly on crust this old. Later drilling just north of Baby Bare at ODP Site 1026 found the temperature of fluids in the uppermost basement to be $63.8^{\circ} \mathrm{C}$ (Davis et al., 1997; Fisher et al., 1997); these waters apparently cool conductively to $25^{\circ} \mathrm{C}$ during their ascent beneath the Baby Bare springs.

\section{METHODS}

Spring fluids were sampled by DSV Alvin both directly and through dome-shaped inverted funnels that were deployed to concentrate the flow; one spring so capped delivered $0.02 \mathrm{~L} \mathrm{~s}^{-1}$ at $0.02 \mathrm{~cm} \mathrm{~s}^{-1}(5000$ $\mathrm{m} \mathrm{yr}^{-1}$ ) into the base of the funnel. Spring-fluid samples for dissolved gas analysis were collected with titanium gas-tight samplers in conjunction with the NOAA manifold sampler (Massoth et al., 1989). Other spring fluid samples were collected with titanium-syringe majors samplers (Von Damm et al., 1985) operated in conjunction with the manifold sampler. Bottom seawater samples were collected with a Niskin bottle attached to Alvin's sample basket.

Gas samples were acidified with sulfamic acid to $\mathrm{pH}<2$, and the gases were then vacuum-extracted at sea with a glass/stainless-steel vacuum line. The total gas volume was determined with high precision capacitance manometers, and the extracted gas from each sample was sealed in several breakseal glass ampoules for analysis ashore. The extracted spring-fluid gases were analyzed by cryogenic gas chromatography (6-m Haysep-Q analytical column operated from $-50^{\circ} \mathrm{C}$ to $70^{\circ} \mathrm{C}$ ) to separate $\mathrm{H}_{2}, \mathrm{O}_{2}, \mathrm{Ar}, \mathrm{N}_{2}, \mathrm{CH}_{4}, \mathrm{CO}$, and $\mathrm{CO}_{2}$ with a single injection. The samples were injected by means of a sample loop valve attached to a high-vacuum inlet system; the sample inlet pressure was monitored with a capacitance manometer. The precision of the total $\mathrm{CO}_{2}\left(\mathrm{TCO}_{2}\right)$ measurements was $\pm 2 \%$. Analyses for the stable carbon isotopic composition of dissolved total $\mathrm{CO}_{2}\left(\delta^{13} \mathrm{C}-\mathrm{TCO}_{2}\right)$ used subsamples of the extracted spring fluid gases which were processed offline using conventional techniques, sealed in glass ampoules, and analyzed using a Finnigan-MAT 252 mass spectrometer. The precision of the isotopic measurements was 0.05 per mil. Alkalinity analyses were made aboard ship by potentiometric Gran titration $( \pm 0.02 \mathrm{meq}$ $\mathrm{L}^{-1}$ ). Measurements of $\mathrm{Ca}^{2+}$ and $\mathrm{Mg}^{2+}$ were made by colorimetric titration $( \pm 0.2 \%$; Kremling, 1983$)$ for the titanium-syringe samples, and by inductively coupled plasma atomic emission spectroscopy $( \pm 3 \%)$ for the gas-tight samples.

\section{RESULTS AND DISCUSSION}

\subsection{Spring Fluid Composition}

The lowest $\mathrm{Mg}^{+2}$ concentration measured in the Baby Bare spring samples was $0.98 \mathrm{mmol} \mathrm{kg}^{-1}$ (Fig. 2a). As with other submarine hydrothermal systems, we assume that this small amount of $\mathrm{Mg}^{+2}$ is a contaminant from seawater introduced during sampling and that the endmember (undiluted by seawater) spring fluid has a $\mathrm{Mg}^{2+}$ concentration of $0 \mathrm{mmol} \mathrm{kg}{ }^{-1}$ (e.g., Von Damm et al., 1985; Seyfried and Mottl, 1995); this assumption is supported by the Baby Bare sediment porewater $\mathrm{Mg}^{+2}$ concentrations, which converge on $0 \mathrm{mmol} \mathrm{kg}{ }^{-1}$ with depth (Mottl et al., 1998). From this assumption we can extrapolate añ endmember alkalinity of 0.43 meq kg-1 (Fig. 2a), $\sim 1 / 5$ that of bottom seawater $\left(2.44 \mathrm{meq} \mathrm{kg}^{-1}\right.$, Table 1). Similarly, we extrapolate an endmember $\mathrm{Ca}^{2+}$ concentration of $55 \mathrm{mmol} \mathrm{kg}^{-1}$ (Fig. 2b), $\sim 5$ times that of bottom seawater (10.3 $\mathrm{mmol} \mathrm{kg}^{-1}$, Table 1).

Unlike hydrothermal vent fluids previously collected along mid-ocean ridges, the Baby Bare spring fluids, which are the first collected from a ridge flank, are depleted in $\mathrm{TCO}_{2}$ with 
(a)

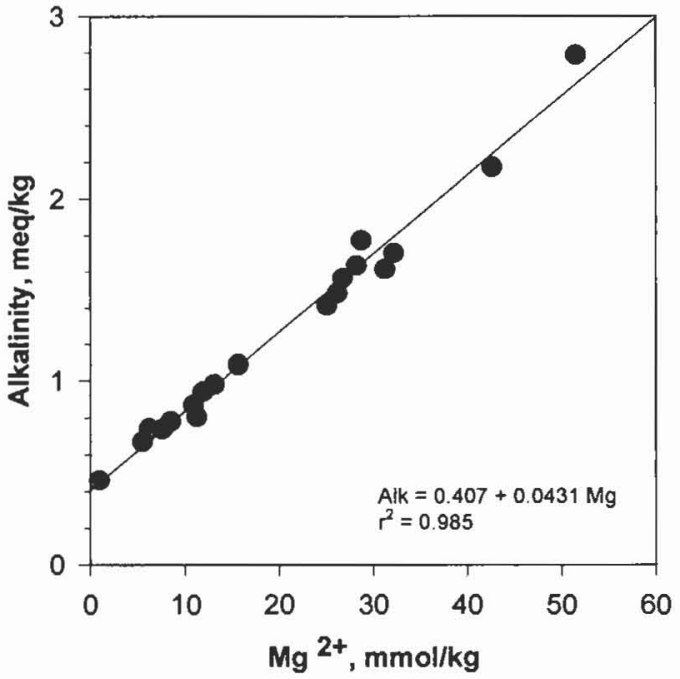

(b)

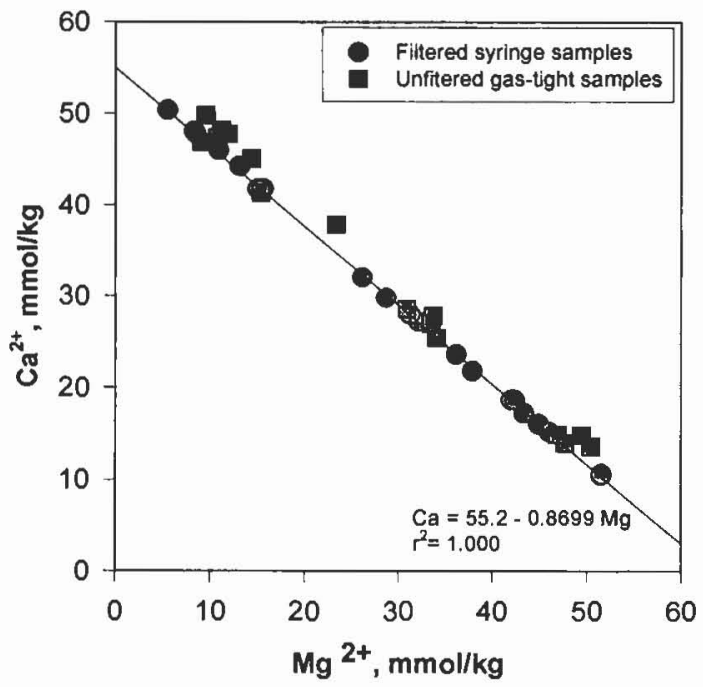

(c)

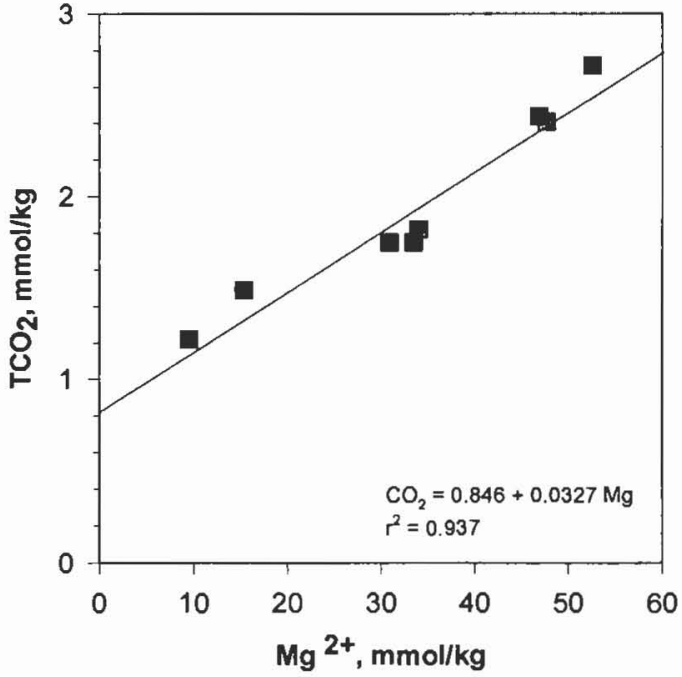

(d)

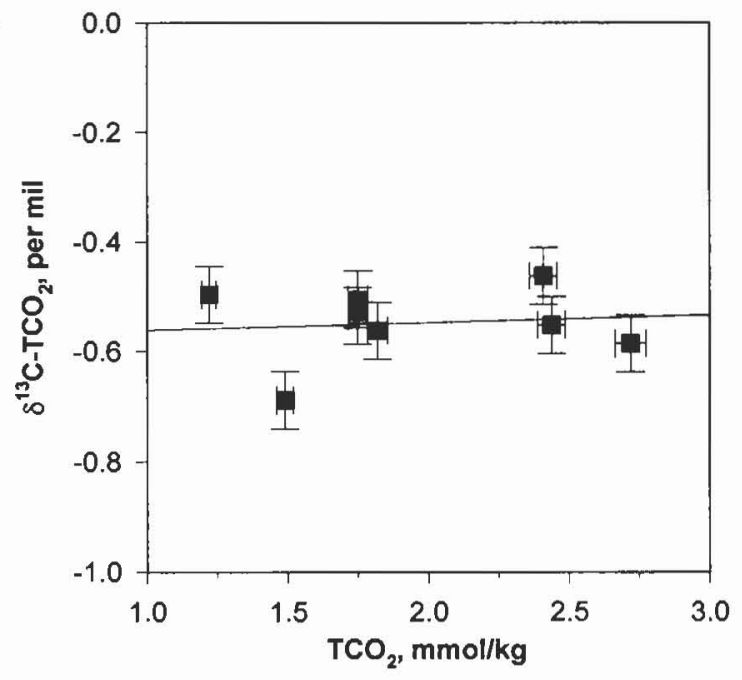

Fig. 2. Composition of Baby Bare spring fluid samples collected with syringe $(\bullet)$ and gas-tight (๘) samplers: (a) titration alkalinity vs, dissolved $\mathrm{Mg}^{2+}$, (b) dissolved $\mathrm{Ca}^{2+}$ vs. dissolved $\mathrm{Mg}^{2+}$, (c) $\mathrm{TCO}_{2}$ vs. dissolved $\mathrm{Mg}^{2+}$, and (d) $\delta^{13} \mathrm{C}-\mathrm{TCO}_{2}$ vs. $\mathrm{TCO}_{2}$. Lines are linear regressions of the data; only the syringe-sample data are included in the regression in (b). Data plotted in (c) and (d) are for the eight gas-tight samples which plotted on the syringe-sample $\mathrm{Mg}$-Ca regression line in (b). Error bars in (d) indicate the analytical errors.

respect to seawater (Fig. 2c). Note, however, that the gas-tight samples were not filtered before processing, so it is possible that carbonate particles suspended in the samples may have led to erroneous $\mathrm{TCO}_{2}$ values due to sample acidification before gas analysis. Thus we have only used data from gas-tight samples that fell upon the Ca-Mg regression line obtained from the filtered titanium-syringe majors samples (Fig. 2b). These selected samples yield an extrapolated endmember $\mathrm{TCO}_{2}$ concentration of $0.85 \mathrm{mmol} \mathrm{kg}^{-1}$ (Fig. 2c), which is only $\sim 1 / 3$ that of bottom seawater.

The spring-fluid ${ }^{13} \mathrm{C}-\mathrm{TCO}_{2}$ values are largely invariant with respect to $\mathrm{TCO}_{2}$ concentration (Fig. 2d), indicating that the process(es) responsible for the $\mathrm{TCO}_{2}$ removal do not strongly isotopically fractionate the spring-fluid $\mathrm{TCO}_{2}$. In contrast, significant amounts of isotopic fractionation, with preferential removal of light $\mathrm{TCO}_{2}$, would be expected if biological $\mathrm{TCO}_{2}$ uptake (such as in $\mathrm{CO}_{2}$ reduction to $\mathrm{CH}_{4}$ ) was a major carbon
Table 1. Chemical and physical characteristics of the Baby Bare endmember spring fluid and bottom seawater (2650 $\mathrm{m}$ depth).

\begin{tabular}{lcc}
\hline & $\begin{array}{c}\text { Computed } \\
\text { endmember }\end{array}$ & $\begin{array}{c}\text { Bottom } \\
\text { seawater }\end{array}$ \\
\cline { 2 - 3 } Total $\mathrm{CO}_{2}\left(\mathrm{mmol} \mathrm{kg}^{-1}\right)$ & $0.85 \pm 0.2$ & $2.38^{\mathrm{B}}$ \\
Alkalinity $\left(\mathrm{meq} \mathrm{kg}^{-1}\right)$ & $0.43 \pm 0.07^{\mathrm{b}}$ & $2.44^{\mathrm{B}}$ \\
$\mathrm{Mg}^{2+}\left(\mathrm{mmol} \mathrm{kg}^{-1}\right)$ & 0 & $52^{\mathrm{b}}$ \\
$\mathrm{Ca}^{2+}\left(\mathrm{mmol} \mathrm{kg}^{-1}\right)$ & $55.2^{\mathrm{b}}$ & $10.3^{\mathrm{b}}$ \\
${\mathrm{Temperature}\left({ }^{\circ} \mathrm{C}\right)}^{\mathrm{B}} \mathrm{GEOSECS} \mathrm{Stn} \mathrm{217,} \mathrm{Craig} \mathrm{et} \mathrm{al.} \mathrm{(1981)}$ \\
$\begin{array}{l}\text { bWheat et al. (1995) } \\
{ }^{\mathrm{c} D a v i s ~ e t ~ a l . ~(1997) ~}\end{array}$
\end{tabular}


sink (e.g., Nissenbaum et al., 1972). Conversely, inorganic precipitation of $\mathrm{CaCO}_{3}$ would be expected to exhibit at most a small degree of fractionation, with preferential removal of heavy $\mathrm{TCO}_{2}$ (e.g., Romanek et al., 1992); this is consistent with the weak trend seen in Fig. 2d.

\subsection{Ridge-Flank Seafloor Alteration}

Low-temperature seafloor alteration has been suggested as a possible long-term control on such factors as the alkalinity budget of seawater and atmospheric $\mathrm{CO}_{2}$ levels (Staudigel et al., 1989; Spivack and Staudigel, 1994). In contrast, recent modeling by Caldeira (1995) indicates that terrestrial silicaterock weathering is a more important control on long-term atmospheric $\mathrm{CO}_{2}$ content than is low-temperature oceanic basalt alteration. In light of the paucity of oceanic crustal samples that could help resolve these issues, the availability of hydrothermal fluids from a ridge-flank hydrothermal system offers an attractive alternative approach for addressing this controversy.

We propose that the extensive $\mathrm{TCO}_{2}$ and alkalinity removal in the Baby Bare spring fluids is associated with calcium carbonate precipitation in the underlying basement during offaxis hydrothermal alteration of the oceanic crust. Such carbonate precipitation would be promoted by the elevated $\mathrm{Ca}^{2+}$ concentrations $\left(55 \mathrm{mmol} \mathrm{kg}{ }^{-1}\right.$ ) in the spring fluids (Wheat et al., 1995; Mottl et al., 1998), presumably the result of basalt weathering. The strong linear relationship between $\mathrm{TCO}_{2}$ and $\mathrm{Mg}^{2+}$ indicates a predominantly hydrothermal control on spring fluid $\mathrm{TCO}_{2}$ concentrations. In addition, ridge-flank carbonate precipitation has previously been postulated on the basis of (1) analyses of DSDP/ODP cores, in which calcium carbonate appears to be a major product of late-stage hydrothermal alteration of mid-ocean ridge basalts (e.g., Alt and Honnorez, 1984; Alt et al., 1986, 1992; Alt, 1995; Teagle et al., 1996), (2) the apparent increase in carbonate content of oceanic crust with increasing age (Staudigel et al,, 1981; Alt, 1993), and (3) thermodynamic calculations and experimental results (Brady and Gíslason, 1997). Calcium carbonates and zeolites have been identified as the last secondary phases to form at temperatures $\angle 250^{\circ} \mathrm{C}$ under such conditions; these seawater-basement reactions can be approximated as:

$$
\begin{gathered}
\mathrm{CaSiO}_{3}+2 \mathrm{CO}_{2}+\mathrm{H}_{2} \mathrm{O} \rightarrow \mathrm{Ca}^{2+}+2 \mathrm{HCO}_{3}^{-}+\mathrm{SiO}_{2} \\
\mathrm{Ca}^{2+}+2 \mathrm{HCO}_{3}^{-} \rightarrow \mathrm{CaCO}_{3}+\mathrm{CO}_{2}+\mathrm{H}_{2} \mathrm{O} \\
\mathrm{CaSiO}_{3}+\mathrm{CO}_{2} \rightarrow \mathrm{CaCO}_{3}+\mathrm{SiO}_{2}
\end{gathered}
$$

where $\mathrm{CaSiO}_{3}$ in this case represents the calcium silicate component of primary igneous minerals in basalt. Such a reaction scheme was originally proposed by Urey $(1952,1956)$ to predict limits on atmospheric $\mathrm{CO}_{2}$ levels over geological time. Finally, the carbonates recovered at DSDP Sites 417 and 896 were low-Mg (0-5 mol\% $\left.\mathrm{MgCO}_{3}\right)$, implying that they were formed from seawater solutions with lowered $\mathrm{Mg} / \mathrm{Ca}$ ratios (Alt and Honnorez, 1984; Teagle et al., 1996); again, this is consistent with the chemistry of Baby Bare spring fluids, which had endmember $\mathrm{Mg} / \mathrm{Ca}$ ratios of $<0.02$, compared to the seawater ratio of 5.1 (Table 1).

Mottl and Wheat (1994) estimated that a global heat loss of $50 \times 10^{18} \mathrm{cal} \mathrm{yr}^{-1}(6.6 \times 10 \mathrm{TW})$ resulted from convection of seawater through mid-ocean ridge flanks. They showed that if only $8-20 \%$ of this heat was lost by advection at temperatures $\geq 25^{\circ} \mathrm{C}$, as measured at the sediment/basement interface, then this type of ridge-flank hydrothermal circulation could remove into the crust the entire river input of $\mathrm{Mg}$. Disposal of this much $\mathrm{Mg}$ sets an approximate upper limit to the rate of advection at these relatively warm basement temperatures, as typified by the Baby Bare springs, and allows us to estimate an upper limit on carbon fluxes into oceanic crust by this process. Assuming that the $\mathrm{TCO}_{2}$ concentrations of other endmember ridge-flank spring fluids at $\geq 25^{\circ} \mathrm{C}$ are similar to those of the computed Baby Bare endmember, an upper limit on the global carbon sink associated with warm ridge-flank hydrothermal circulation can be calculated:

$$
S_{C}=\frac{H_{g} f r_{C}}{c T}
$$

where $S_{C}$ is the global carbon sink, $H_{g}$ is the global ridge-flank heat flux $\left[64 \pm 11 \times 10^{18} \mathrm{cal} \mathrm{yr}^{-1}(8.6 \pm 1.6 \mathrm{TW}\right.$; Mottl and Wheat, 1994)], $f$ is the fraction of $H_{g}$ that is due to warm ridge-flank venting (i.e., that with temperatures in the uppermost basement of $\geq 25^{\circ} \mathrm{C}$ ), $\mathrm{r}_{\mathrm{C}}$ is the $\mathrm{TCO}_{2}$ removed $\left(\mathrm{mol} \mathrm{kg}{ }^{-1}\right.$ ) from bottom seawater during the formation of endmember spring fluid, $\mathrm{c}$ is the specific heat of water $\left(955 \mathrm{cal}^{\circ} \mathrm{C}^{-1} \mathrm{~kg}^{-1}\right)$, and $\mathrm{T}$ is elevation of the temperature of the basement hydrothermal fluids with respect to the $2^{\circ} \mathrm{C}$ bottom seawater. Using the endmember and seawater temperatures and $\mathrm{TCO}_{2}$ concentrations given in Table 1, and the Mottl and Wheat (1994) maximum estimate for $f$ of $0.08-0.20$, a flux of $1.0-2.6 \times 10^{11}$ mol $\mathrm{yr}^{-1}\left(1.2-3.1\right.$ Mton-C $\left.\mathrm{yr}^{-1}\right)$ is calculated as an upper limit for the global carbon sink in warm ridge flanks. Note that the choice of temperature is not especially critical: the composition of basement water on the eastern flank of the Juan de Fuca Ridge, as inferred from the sediment porewater data from ODP Leg 168 (Davis et al., 1997), indicates that $r_{C}$ is approximately proportional to $\mathrm{T}$ over the relevant temperature range of 25 $65^{\circ} \mathrm{C}$ for warm ridge-flank circulation (i.e., changes in $r_{C}$ and $\mathrm{T}$ in Eqn. 4 will cancel out).

This net flux is an order of magnitude lower than the 22-29 $\times 10^{11} \mathrm{~mol} \mathrm{yr}^{-1}$ value of Staudigel et al. (1989) for global carbon uptake by ridge axis and flank seafloor alteration, derived from estimates of carbon accumulation in $120 \mathrm{Ma}$-old hydrothermally altered oceanic crust from DSDP Sites 417 and 418. Conversely, our estimate is similar to the $1.5-3.5 \times 10^{11}$ mol $\mathrm{yr}^{-1}$ value calculated by Alt et al. (1996) for ridge flank seafloor alteration using carbon accumulation data from ODP Sites 504 and 896 on 6 Ma-old crust. It is possible that this difference reflects the very different crustal ages at these two localities: perhaps the younger crust reflects uptake of carbon from warmer waters, whereas the older crust has taken up carbon from cooler waters as well. If the other $80-92 \%$ of the heat lost by advection on ridge flanks occurs at basement temperatures of $5-25^{\circ} \mathrm{C}$ and is accompanied by a loss in $\mathrm{TCO}_{2}$ that is only $10 \%$ of that in the Baby Bare spring water, the calculated carbon flux is $2.8-25 \times 10^{11} \mathrm{~mol} \mathrm{yr}^{-1}$, much larger than estimated above for warmer flow even though the $\mathrm{Mg}$ flux would still be less than the annual river flux; a larger $\mathrm{TCO}_{2}$ loss results in an even higher carbon flux into the crust. However, as noted by both Staudigel et al. (1989) and Alt et al. (1996), there 
is considerable uncertainty in their estimates due to the natural inhomogeneity of the ridge-flank volcanics and the limited number of samples thus far examined. For comparison, these calculated fluxes are considerably smaller than current estimates of combined subaerial and submarine volcanic $\mathrm{CO}_{2}$ emissions (e.g., 60-70 $\times 10^{11} \mathrm{~mol} \mathrm{y} \mathrm{y}^{-1}$ (Holland, 1978), $110 \times 10^{11} \mathrm{~mol} \mathrm{yr}^{-1}$ (Berner, 1990), 30-40 $\times 10^{11} \mathrm{~mol} \mathrm{yr}^{-1}$ (Gerlach, 1991), $50 \times 10^{11} \mathrm{~mol} \mathrm{yr}^{-1}$; Mackenzie, 1995).

In a similar fashion, it is possible to use the Baby Bare spring fluid data to estimate the global alkalinity sink associated with warm ridge-flank hydrothermal reactions:

$$
S_{A}=\frac{H_{g} f r_{A}}{c T}
$$

where $S_{A}$ is the global alkalinity sink, $r_{A}$ is the alkalinity removed ( $\mathrm{eq} \mathrm{kg}^{-1}$ ) from bottom seawater during the formation of endmember hydrothermal fluid, and the other variables are the same as for Eqn. 4. Again using the data in Table 1, the

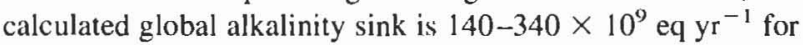
ridge flank hydrothermal systems with temperatures $\geq 25^{\circ} \mathrm{C}$.

This net flux is comparable to the global acidity flux of $350 \pm 300 \times 10^{9} \mathrm{eq} \mathrm{yr}^{-1}$ estimated by Spivack and Staudigel (1994) for low-temperature alteration of the upper oceanic crust. As noted by these authors, fluxes of such magnitude are only a few percent of the global primary alkalinity flux, indicating that low-temperature weathering of the upper crust at temperatures $\geq 25^{\circ} \mathrm{C}$ is not a significant factor in the global alkalinity budget. However, weathering at temperatures $<25^{\circ} \mathrm{C}$ may be a more significant global flux.

Finally, the Baby Bare spring fluid data indicate that the observed loss of alkalinity is not solely due to $\mathrm{CaCO}_{3}$ precipitation. If $\mathrm{CaCO}_{3}$ precipitation were solely responsible, the $\mathrm{r}_{\mathrm{A}}: \mathrm{r}_{\mathrm{C}}$ ratio would be $\sim 2 \mathrm{eq} \mathrm{mol}^{-1}$, rather than the observed value of $2.01: 1.53=1.31 \mathrm{eq} \mathrm{mol}^{-1}$. It is likely that the additional alkalinity loss is associated with hydrothermal basalt-seawater reactions that remove $\mathrm{Mg}^{+2}$ (e.g., Bischoff and Dickson, 1975).

\section{CONCLUSIONS}

The data presented here indicate that ridge-flank hydrothermal fuids can be highly depleted in $\mathrm{TCO}_{2}$ with respect to the original seawater. However, hydrothermal alteration of oceanic crust on young mid-ocean ridge flanks at temperatures of a few tens of degrees Celsius is only a relatively minor sink for carbon on a global basis. It is still possible, however, that ridge-flank alteration at lower temperatures $\left(<25^{\circ} \mathrm{C}\right)$ is an important component of the global carbon budget. Although these data are not sufficient to determine unequivocally the roles of oceanic crust alteration on global carbon cycling, they do indicate that these processes merit consideration in global carbon models. In particular, as pointed out by Caldeira (1995), ocean basement carbon accumulation may be particularly important in assessing the impact of subduction zone metamorphism on atmospheric $\mathrm{CO}_{2}$ content.

There is clearly a strong need for similar studies at other ridge-flank sites to determine the consistency of spring fluid composition and the rate of venting (both as discrete springs and as more diffuse upward_porewater advection) at such sites. This is particularly important in light of the observed hetero- geneity in off-axis alteration due to such factors as basement temperature and the degree of restriction of circulation of hydrothermal fluids (e.g., Alt, 1995; Alt et al., 1996; Teagle et al., 1996). However, despite the uncertainties in our knowledge of ridge-flank crustal alteration, the carbon and alkalinity removal estimates presented here should be a useful first step in quantitatively evaluating the role of off-axis venting in global hydrothermal chemical fluxes.

Acknowledgments - We thank the officers and crew of DSV Alvin and RV Atlantis II for their help in making the Baby Bare dives such a success. We also thank Brian Popp and Terri Rust for their assistance with the isotopic analyses; and Jeff Alt, Fred Mackenzie, and Steve Smith for discussions of the data. This research was funded by U.S, National Science Foundation grants OCE-9314632 10 M.J.M. and C.G.W., and OCE-9314394 to F.J.S. This is SOEST Contribution No. 4660 .

\section{REFERENCES}

Alt J. C. (1993) Low-temperalure alteration of basalts from the Hawaiian Arch, Leg 136. Proc. Ocean Drill. Prog., Sci. Results 136, $133-146$.

Alt J. C. (1995) Subseafloor processes in mid-ocean ridge hydrothermal systems. In Seafloor Hydrothermal Systems: Physical, Chemical, Biological, and Geological Interactions (ed. S. E. Humphris et al.); Geophys. Monogr. 91, 85-114. AGU.

Alt J. C. and Honnorez J. (1984) Alteration of the upper oceanic crust, DSDP site 417: Mineralogy and chemistry. Contrib. Mineral Petrol. 87, $149-169$

Alt J. C.. Honnorez J., Laverne C., and Emmermann R. (1986) Hydrothermal alteration of a $1 \mathrm{~km}$ section through the upper oceanic crust, Deep Sea Drilling Program hole 504B. J. Geophys. Res. 91, 10,30910,335 .

Alt J. C., France-Lanord C., Floyd P. A., Castillo P., and Galy A. (1992) Low temperature hydrothermal alteration of Jurassic ocean crust. Proc. Ocean Drill. Prog., Sci. Results 129, $415-427$.

Alt J. C. et al. (1996) Ridge flank alteration of upper ocean crust in the eastern Pacific: A synthesis of results for volcanic rocks in holes 504B and 896A. Proc. Ocean Drill. Prog., Sci. Results 148, 435452.

Anderson R. N., Langseth M. G., and Sclater J. G. (1977) The mechanisms of heat transfer through the floor of the Indian Ocean. J. Geophys. Res. 82, 3391-3409.

Anderson R. N., Hobart M. A., and Langseth M. G. (1979) Geothermal convection through oceanic crust and sediments in the Indian Ocean. Science 204, 828-832.

Berner R. A. (1990) Global $\mathrm{CO}_{2}$ degassing and the carbon cycle: Comment on Cretaceous ocean crust at the DSDP sites 417 and 418 Carbon uptake from weathering vs. loss by magmatic outgassing. Geochim. Cosmochim. Acta 54, 2889-2890.

Bischoff J. L. and Dickson F. W. (1975) Seawater-basalt interaction at $200^{\circ} \mathrm{C}$ and 500 bars: Implications for origin of seafloor heavy metal deposits and regulation of seawater chemistry. Earth Planet. Sci. Lett. 25, 385-397.

Brady P. V. and Gíslason S. R. (1997) Seafloor weathering controls on atmospheric $\mathrm{CO}_{2}$ and global climate. Geochim. Cosmochim. Acta 61, 965-973.

Caldeira K. (1995) Long-term control of atmospheric carbon dioxide: Low-temperature seafloor alteration or terrestrial silicate-rock weathering. Amer. J. Sci. 295, 1077-1114.

Craig H., Broecker W. S., and Spencer D. (1981) GEOSECS Pacific Expedition, Vol. 4, Sections and Profiles. NSF.

Davis E. E., Chapman D. S., Forster C. B., and Villinger H. (1989) Heat-flow correlated with buried basement topography on the Juan de Fuca Ridge flank. Nature 342, 533-537.

Davis E. E. et al. (1992) FlankFlux: An experiment to study the nature of hydrothermal circulation in young oceanic crust. Canadian $J$. Earth Sci. 29, 925-952.

Davis E. E. et al. (1997) Proc. Ocean Drilling Program, Initial Reports 168. Ocean Drill. Prog. College Station. 
Fisher A., Becker K., and Davis E. E. (1997) The permeability of young oceanic crust east of Juan de Fuca Ridge, as determined using borehole thermal measurements. Geophys. Res. Lett. 24, 1311-1314.

François L. M. and Walker J. C. G. (1992) Modeling the Phanerozoic carbon cycle and climate: Constraints from the ${ }^{87} \mathrm{Sr} /{ }^{86} \mathrm{Sr}$ isotopic ratio of seawater, Amer. J. Sci. 292, 81-135.

Gerlach T. M. (1991) Present-day $\mathrm{CO}_{2}$ emissions from volcanos. Eos, Trans. Amer. Geophys. Union Trans. Amer. Geophys. Union 72, 249, 254-255

Gieskes J. M. (1983) The chemistry of interstitial waters of deep sea sediments: Interpretation of deep sea drilling data. In Chemical Oceanograph., Vol. 8, pp. 222-269. Academic Press.

Holland H. D. (1978) The Chemistry of the Atmosphere and Oceans. Wiley.

Kadko D., Baross J., and Alt J. (1995) The magnitude and global implications of hydrothermal flux. In Seafloor Hydrothermal Systems: Physical, Chemical, Biological, and Geological Interactions; Geophys. Monogr. 91, 446-465. AGU.

Kremling K. (1983) Determination of the major constituents. In Methods of Seawater Analysis (ed. K. Grasshoff et al.), pp. 247-268. Verlag Chemie.

Langseth M. G. and Anderson R. N. (1979) Correction. J. Geophys. Res. 84, 1139

Lawrence J. R., Gieskes J. M., and Broecker W. S. (1975) Oxygen isotope and cation composition of DSDP porewaters and the alteration of Layer II basalts. Earth. Planet. Sci. Lett. 27, 1-10.

Mackenzie F. T. (1995) Global climatic change: Climatically important biogenic gases and feedbacks. In Biotic Feedbacks in the Global Climatic System: Will the Warming Feed the Warming? (ed. G. M. Woodwell and F. T. Mackenzie), pp. 22-46. Oxford Univ. Press.

Massoth G. J., Milburn H. B., Hammond S. R., Butterfield D. A., McDuff R. E., and Lupton J. E. (1989) The geochemistry of submarine venting fluids at Axial Volcano, Juan de Fuca Ridge: New sampling methods and a VENTS program rationale. In Global Venting, Midwater, and Benthic Ecological Processes (ed. M. P. De Luca and I. Babb), pp. 29-59. Nat. Undersea Res. Prog. Res. Rep. 88-4.

Mottl M. J. (1989) Hydrothermal convection, reaction, and diffusion in sediments on the Costa Rica Rift flank: Porewater evidence from ODP Sites 677 and 678. Proc. Ocean Drill. Prog., Sci. Results 111, 195-213.

Mottl M. J. and Wheat C. G. (1994) Hydrothermal circulation through mid-ocean ridge flanks: Heat and magnesium fluxes. Geochim. Cosmochim. Acta. 58, 2225-2237.

Mottl M. J., Lawrence J. R., and Keigwin L. D. (1983) Elemental and stable-isotopic composition of porewaters and carbonate sediments from Deep Sea Drilling Project Sites 501/504 and 505. In lnit. Repts. Deep Sea Drill. Proj. Vol. 69 (ed. J. R. Cann et al.), pp. 461-473. U.S. Govt. Print. Office.

Mottl M. J. et al. (1995) Warm springs discovered on 3.4 Ma-old crust, Baby Bare Outcrop, eastern flank of the Juan de Fuca Ridge: FlankFlux 95. Eos, Trans. Amer. Geophys. Union 76 (suppl.), F419 (abstr.).

Mottl M. J. et al. (1998) Warm springs discovered on 3.4 Ma-old oceanic crust, Baby Bare Outcrop, eastern flank of the Juan de Fuca Ridge. Geology 26, 51-54.

Nissenbaum A., Presley B. J., and Kaplan I. R. (1972) Early diagenesis in a reducing fjord, Saanich Inlet, British Columbia - I. Chemical and isotopic changes in major constituents of interstitial water. Geochim. Cosmochim. Acra 36, 1007-1027.

Romanek C. S., Grossman E. L., and Morse J. W. (1992) Carbon isotopic fractionation in synthetic aragonite and calcite: Effects of temperature and precipitation rate. Geochim. Cosmochim. Acta 56, $419-430$.

Sayles F. L. and Manheim F. T. (1975) Interstitial solutions and diagenesis in deeply buried marine sediments: Results from the Deep Sea Drilling Project. Geochim. Cosmochim. Acta 39, 103-127.

Seyfried W. E., Jr. and Mottl M. J. (1995) Geologic setting and chemistry of deep-sea hydrothermal vents. In The Microbiology of Deep-Sea Hydrothermal Vents (ed. D. M. Karl), pp. 1-34. CRC Press.

Sclater J. G., Jaupart C., and Galson D. (1980) The heat flow through oceanic and continental crust and the heat loss of the earth. Rev Geophys. Space Phys. 18, 269-311.

Sleep N. H. and Wolery T. J. (1978) Egress of hot water from midocean ridge hydrothermal systems: Some thermal constraints. J. Geophys. Res. 83, 5913-5922.

Spivack A. J. and Staudigel H. (1994) Low-temperature alteration of the upper oceanic crust and the alkalinity budget of seawater. Chem. Geol. 115, 239-247.

Staudigel H. and Hart S. R. (1983) Alteration of basaltic glass: Mechanisms and significance from the oceanic crust-seawater budget. Geochim. Cosmochim. Acta 47, 337-350.

Staudigel H., Hart S. R, and Richardson S. (1981) Alteration of the oceanic crust: Processes and timing. Earth Planet. Sci. Lett. 52, 311-327.

Staudigel H., Hart S. R., Schmincke H.-U., and Smith B. M. (1989) Cretaceous ocean crust at the DSDP sites 417 and 418: Carbon uptake from weathering vs. loss by magmatic outgassing. Geochim. Cosmochim. Acta 53, 3091-3094.

Staudigel H., Hart S. R., Schmincke H.-U., and Smith B. M. (1990) Reply to "Global $\mathrm{CO}_{2}$ degassing and the carbon cycle": A Comment by R. A. Berner. Geochim. Cosmochim. Acta 54, 2891.

Teagle D. A. H., Alt J. C., Bach W., Halliday A. N., and Erzinger J. (1996) Alteration of upper ocean crust in a ridge-flank hydrothermal upflow zone: Mineral, chemical, and isotopic constraints from Hole 896A. Proc. Ocean Drilling Prog., Sci. Results 148, 119-150.

Urey H. C. (1952) The Planets, Their Origin and Development. Yale Univ. Press.

Urey H. C. (1956) Regarding the early history of the Earth's atmosphere. Bull. Geol. Soc. Amer. 67, 1125-1128.

Von Damm K. L., Edmond J. M., Grant G., Measures C. I., Walden B., and Weiss R. F. (1985) Chemistry of submarine hydrothermal solutions at $21^{\circ}$ N, East Pacific Rise. Geochim. Cosmochim. Acta 49, 2197-2220.

Wheat C. G. and Mottl M. J. (1994) Hydrothermal circulation, Juan de Fuca eastern flank: Factors controlling basement water composition. J. Geophys. Res. 99, 3067-3080.

Wheat C. G., Mottl M. J., Davis E. E., and Baker E. T. (1995) Mass, thermal, and chemical fluxes from a ridge-flank hydrothermal system: FlankFlux (FF 90-95). Eos, Trans. Amer. Geophys. Union 76 (suppl.), F419 (abstr.).

Wolery T. J. and Sleep N. H. (1976) Hydrothermal circulation and geochemical flux at mid-ocean ridges. J. Geol. 84, 249-275. 